ISSN 1392-3196 / e-ISSN 2335-8947

Zemdirbyste-Agriculture, vol. 108, No. 2 (2021), p. 165-172

DOI 10.13080/z-a.2021.108.022

\title{
The occurrence and control of black bean aphid (Aphis fabae Scop.) in broad bean
}

\author{
Mohammad ALMOGDAD, Roma SEMAŠKIENĖ \\ Lithuanian Research Centre for Agriculture and Forestry \\ Instituto 1, Akademija, Kèdainiai distr., Lithuania \\ E-mail: mohammad.almogdad@lammc.lt
}

\begin{abstract}
To assess changes in the population of black bean aphid (Aphis fabae Scop.) in relation to the cultivar and timing of pest control using insecticides, precision field experiment was carried out in the fields of broad bean (Vicia faba L.). The research was conducted on three broad bean cultivars 'Tiffany', 'Fuego' and 'Vertigo' during three successive growing seasons in 2018, 2019 and 2020 at different sites with a distance between the experimental fields of 1-2 km. The experiment included five insect pest control regimes. The population of black bean aphid was monitored from the beginning of germination by using yellow traps and by counting percent of damaged plants. Assessments of black bean aphid's abundance were done at beginning of flowering to pod development stage. The infestation of black bean aphids on the plants of broad bean cultivars was affected by different spray regimes. All the tested broad bean cultivars were variably infested with Aphis fabae. The experimental data suggest that among the three cultivars tested the most susceptible to A. fabae was 'Tiffany', while 'Fuego' and 'Vertigo' supported a low population density of this pest. Insecticide application according to the local threshold resulted in a significantly lower aphid population compared to the untreated, and the efficacy was similar to that of the full control treatment.

The data from four field trials obtained during the three growing seasons suggest that $A$. fabae infestation can incur a grain yield reduction of $0.21 \mathrm{t} \mathrm{ha}^{-1}$. Applications according to local threshold with contact and systemic insecticides increased grain yield at the same level, and it was in line with the full control treatment.
\end{abstract}

Key words: Aphis fabae, abundance, insecticide, local threshold, Vicia faba, yield.

\section{Introduction}

Black bean aphid (Aphis fabae Scop.) is spread almost worldwide (Esmaeili-Vardanjani et al., 2013). It occurs throughout Europe, Western Asia, Africa and South America (Meradsi, Laamari, 2018). It attacks all plant parts and prefers the newly growing plant tips to deposit nymphs (Stoddard et al., 2010) causing growth repression and distortion of leaves, which results in yield losses depending on the infestation time and colonization intensity (Goszczyński et al., 2002). Hansen et al. (2008) suggest that the $A$. fabae is generally considered to be a serious pest of spring-sown field beans in Northern Europe, and field studies have shown that yield losses can exceed $50 \%$ due to attacks from the $A$. fabae.

Thirty years ago, A. fabae was identified as one of the most harmful insect pests in broad bean in Lithuania (Tamošiūnas, 1993). The intense infestation can stimulate dropping or shrivelling of immature pods causing a large loss in yield (Subedi et al., 2018). A. fabae is the main reason for the transmission of plant viruses (Dedryver et al., 2010). It is the main vector for more than 30 plant viruses including the non-persistent viruses in faba bean, peas, beets and potato, and also the persistent viruses like potato leafroll virus (PLRV) and beet yellow net virus (BYNV) (Blackman, Eastop, 2017).

Pyrethroid insecticides are the main class used for foliar application to control the aphids (Johnson et al., 2009), besides the new class of insecticides chemically related to nicotine (neonicotinoids). Some researchers (Rondon, Thompson, 2019) reported no significant differences between insecticide-treated and untreated plots, and others found that neonicotinoids significantly reduced aphid population but not below the economic threshold (Magalhaes et al., 2009). Dotasara et al. (2017) found that neonicotinoids reduced the incidence of mustard aphid (Lipaphis erysimi K.) by $87.53 \%$ over the untreated. Pyrethroid and neonicotinoid insecticides were highly effective against black bean aphid under laboratory conditions (Purhematy et al., 2013). The neonicotinoid insecticide imidacloprid had a high efficacy against $A$. fabae and led to a yield increase compared to the carbamate insecticide carbofuran and to the untreated (Al-Naser, Ezz Al-dden, 2011). Another study found that neonicotinoid insecticides were highly effective against cowpea aphid (Aphis craccivora Koch) compared to the other groups of insecticides (Patil et al., 2017). 
Reasonable application of insecticides is the basis. Therefore, the insecticides should be applied at the proper rate and at the correct time for controlling aphids successfully (Roy et al., 2014). On the other hand, genetic resistance of aphids to insecticides can be delayed by reducing application frequency and treating only when aphid population override the economic threshold (Hodgson et al., 2012).

The research aims to determine the abundance of $A$. fabae pests in the broad bean crops, estimate their harmfulness and identify the most efficient control times in the conventional farming conditions.

\section{Materials and methods}

Experimental site. The experiment was carried at the Institute of Agriculture, Lithuanian Research Centre for Agriculture and Forestry $\left(55^{\circ} \mathrm{N}\right.$ lat., $23^{\circ} \mathrm{E}$ long., 63 $\mathrm{m}$ a.s.1.), Akademija, Kedainiai distr., during the period 2018-2020.

Weather conditions. Monthly air temperatures and precipitation during the growing season months (April to July) were obtained from Dotnuva Meteorological Station, located about $0.5-1.0 \mathrm{~km}$ from the experimental site. The maximum and minimum temperature and the total precipitation were recorded every day. Average of temperatures was recorded for every 10 days, and then the average of the three values was calculated.

Field experiment. Field experiment a total of 6 trials was established during 2018-2020. However, the yield data were evaluated only for four trials, because the threshold was not reached and the application according to the trial design was not done in the 2019 season. Three broad bean (Vicia faba L.) cultivars were grown: 'Tiffany' in 2018 and 2019, 'Vertigo' and 'Fuego' in 2019 and 2020. Broad bean crops were grown according to the recommended agronomic practices, seed rate -0.5 million seeds $\mathrm{ha}^{-1}$. The experiment was laid out in a randomized complete block design. The field was divided into equal plots maintaining a size of $10 \times 2.0$ $\mathrm{m}=20 \mathrm{~m}^{2}, 2$-meter block to block distance and 0.25 meter plot to plot distance. Each treatment was allocated randomly within the block and replicated four times.

Occurrence of Aphid fabae. Monitoring of pests was started at the beginning of germination (BBCH 10) growth stage by using water traps and by counting percent of damaged plants. Assessments of black bean aphid abundance were done four times at growth stages $\mathrm{BBCH}$ 60, 69, 74 and 79 in 2018 and two times at BBCH 65 and 69-70 in 2019 and 2020. The abundance of $A$. fabae was recorded for each plot by taking the black bean aphid (Aphid fabae Scop.) population (both nymph and adult) on the whole plant from each of randomly selected 20 plants per plot. The number of plants infested by $A$. fabae was recorded at $\mathrm{BBCH} 79$. A total of 25 broad bean plants were evaluated within each plot. The infestation level was calculated by the following formula:

$$
\mathrm{IP}=\mathrm{P} 2 / \mathrm{P} 1 \times 100,
$$

where IP is percentage of infested plants, P1 total number of plants checked, P2 - number of infested plants.

To determine the levels of damage to broad bean plants, the percentage of the different infestation densities was estimated at $\mathrm{BBCH} 79$ by plant visual scouting using a scale from 0 to 100 for the total infested area by aphids on the plant, representing $0 \%$ healthy plant and $100 \%$ completely infested plant.

To identify the best aphid control times, field experiment of 6 trials was done during the three growing seasons. Different control regimes were used: 1) untreated (Un); 2) one spray, when the first aphid insect was caught in the yellow water traps; according to the monitoring data (MD), contact (C) insecticide was used (MDC); 3) one spray at the local recommendation, when $20 \%$ of plants are infested by aphids; according to the local threshold $(\mathrm{TH})$, contact $(\mathrm{C})$ insecticide was used $(\mathrm{THC}) ; 4)$ one spray at stem elongation stage $(\mathrm{BBCH}$ $30)$; according to the growth stage (GS), contact (C) insecticide was used (GSC); 5) full control (FC): three sprays at $\mathrm{BCH} 10-13, \mathrm{BBCH} 30$ and $\mathrm{BBCH} 69$ growth stages; contact (C) insecticide was used (FCC); 6) one spray at the local recommendation, when $20 \%$ of plants are infested by aphids; according to the local threshold, systemic insecticide (THS) was used.

Aphid control according to the described spray regimes was done with contact and systemic insecticides. Specifications of insecticides used are provided in Table 1.

Table 1. Description of insecticides used

\begin{tabular}{ccccc}
\hline Commercial product & Active ingredient & Application rate & Chemical sub-group & Mode of action \\
\hline Cyperkill 500 EC & cypermethrin $500 \mathrm{~g} \mathrm{l}^{-1}$ & $0.051 \mathrm{ha}^{-1}$ & pyrethroid & contact \\
Biscaya OD & thiacloprid $240 \mathrm{~g} \mathrm{l}^{-1}$ & $0.31 \mathrm{ha}^{-1}$ & neonicotinoid & systemic \\
\hline
\end{tabular}

Insecticide application date and crop growth stage for each treatment are described in Table 2.

Statistical analysis. The data were recorded and analysed statistically by the software $S A S$, version 7.15 (SAS Institute Inc., USA). The significance of differences was estimated by Duncan's multiple range test at the $P \leq 0.05$ probability level.

\section{Results and discussion}

Occurrence of aphids. The general abundance and the incidence period/time of $A$. fabae differed extremely from season to season under the field conditions in the experimental sites. The infestation level on the tested broad bean cultivars differed between the experimental years. In 2018, the winged $A$. fabae individuals were found in the traps in the first week of
May at BBCH 10, while in 2019 and 2020 they were found in the last week of May at BBCH 15-16 growth stages. The early occurrence in 2018 corresponded with air temperature increasing in April $\left(3.9^{\circ} \mathrm{C}\right.$ warmer than the long-term means) compared with the other years (Figure 1).

The early spring in 2018 was much warmer than in 2019 and 2020 with less precipitation and lower air humidity; hence, insects during the 2018 were exposed to more favourable conditions compared to the other growing seasons. According to Narjary et al. (2013), the abundance of insect pests may differ due to the amount of heat accumulated, day degrees accumulated and humid thermal ratio, which affect the growth and development of insects. Aphid population on 'Tiffany' increased constantly in 2018 and reached the highest amount at BBCH 74 (six weeks after broad bean emergence). 
Table 2. Insecticide application date and broad bean growth stage (BBCH) for Aphis fabae control in 2018-2020

\begin{tabular}{|c|c|c|c|c|}
\hline \multirow{2}{*}{ Treatment } & \multirow{2}{*}{ Year } & \multicolumn{3}{|c|}{ Cultivar } \\
\hline & & 'Tiffany' & 'Fuego' & 'Vertigo' \\
\hline $\begin{array}{l}\text { Untreated } \\
\text { (control) }\end{array}$ & 2018 & - & - & - \\
\hline MDC & $\begin{array}{l}2019 \\
2020 \\
2018 \\
2019 \\
2020\end{array}$ & $\begin{array}{c}- \\
- \\
04 \text { 05, BBCH } 10 \\
2105, \text { BBCH } 15 \\
-\end{array}$ & $\begin{array}{c}- \\
- \\
- \\
2305, \text { BBCH } 15 \\
2605, \text { BBCH } 16\end{array}$ & $\begin{array}{c}- \\
- \\
- \\
2305, \text { BBCH } 15 \\
2605, \text { BBCH } 16\end{array}$ \\
\hline THC & 2018 & 21 06, BBCH 71 & - & - \\
\hline & $\begin{array}{l}2019 \\
2020\end{array}$ & $\begin{array}{c}12 \text { 06, BBCH } 63 \\
-\end{array}$ & $\begin{array}{c}\text { no* } \\
04 \text { 06, BBCH } 50\end{array}$ & $\begin{array}{c}\text { no* } \\
04 \text { 06, BBCH } 33\end{array}$ \\
\hline GSC & $\begin{array}{l}2018 \\
2019 \\
2020\end{array}$ & $\begin{array}{l}28 \text { 05, BBCH } 30 \\
30 \text { 05, BBCH } 30 \\
-\end{array}$ & $\begin{array}{c}- \\
20 \text { 05, BBCH } 30 \\
28 \text { 05, BBCH } 30\end{array}$ & $\begin{array}{c}- \\
2005, \text { BBCH } 30 \\
0306, \text { BBCH } 30\end{array}$ \\
\hline FCC & 2018 & $\begin{array}{l}07 \text { 05, BBCH } 11 \\
28 \text { 05, BBCH } 30 \\
18 \text { 06, ВBCH } 69\end{array}$ & $\begin{array}{l}- \\
- \\
-\end{array}$ & $\begin{array}{l}- \\
- \\
-\end{array}$ \\
\hline & 2019 & $\begin{array}{l}08 \text { 05, BBCH } 12 \\
30 \text { 05, BBCH } 30 \\
25 \text { 06, BBCH } 69\end{array}$ & - & $\begin{array}{l}17 \text { 05, BBCH } 13 \\
24 \text { 05, BBCH } 30 \\
1206, \text { BBCH } 69\end{array}$ \\
\hline THS & 2020 & $\begin{array}{l}- \\
- \\
-\end{array}$ & $\begin{array}{l}30 \text { 04, BBCH } 10 \\
28 \text { 05, BBCH } 30 \\
1906, \text { BBCH } 69\end{array}$ & $\begin{array}{l}04 \text { 05, BBCH } 10 \\
03 \text { 06, ВBCH } 30 \\
1606, \text { BBCH } 69\end{array}$ \\
\hline & $\begin{array}{l}2018 \\
2019 \\
2020\end{array}$ & $\begin{array}{l}21 \text { 06, BBCH } 71 \\
12 \text { 06, BBCH } 63 \\
-\end{array}$ & $\begin{array}{c}- \\
\text { no* } \\
0406, \text { BBCH } 50\end{array}$ & $\begin{array}{c}- \\
\text { no* } \\
0406, \text { BBCH } 33\end{array}$ \\
\hline
\end{tabular}

Note. Contact (C) insecticide was used: MDC - according to monitoring data (MD), THC - according to the local threshold (TH), GSC - according to the growth stage (GS), FCC - full control (application at BBCH 10-13, BBCH 30 and BBCH 69); THS - according to the local threshold, systemic insecticide was used; no* - threshold was not reached.
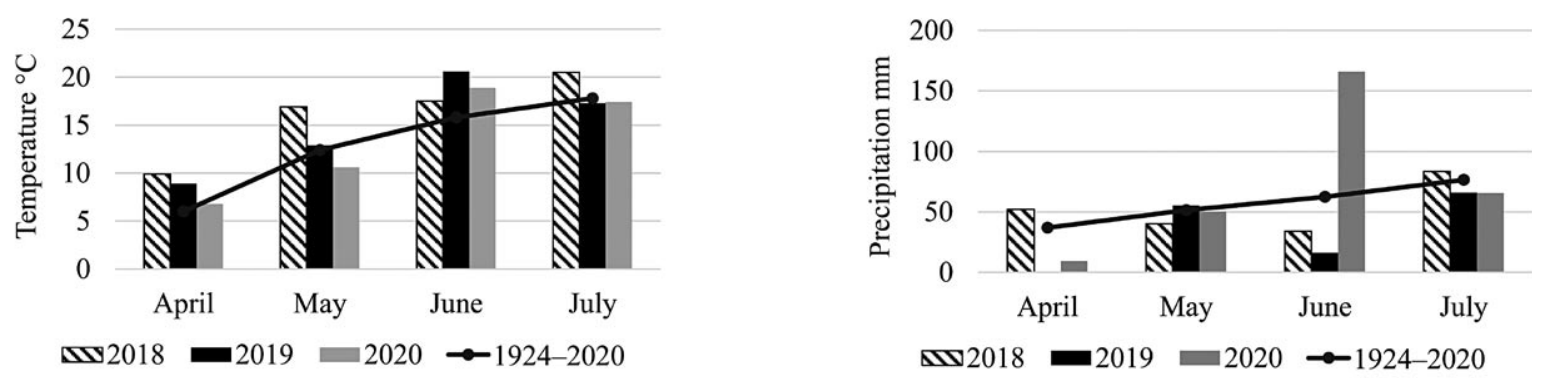

Figure 1. The air temperature and total monthly precipitation during the 2018-2020 growing seasons and the longterm average (1924-2020)

Results of our experiment showed that in the first week of June (at BBCH 30) A. fabae population was 21.8 aphids per plant. It gradually increased to the $23^{\text {rd }}$ of June to 192.5 aphids per plant, thereafter, the population started to decline. Increasing of $A$. fabae population occurred at the pod formation stage and then started to decline slightly as shown in Figure 2.

These results agree with those of Choudhary et al. (2017), who found that the population of cowpea aphid (Aphis craccivora Koch) increased fast with

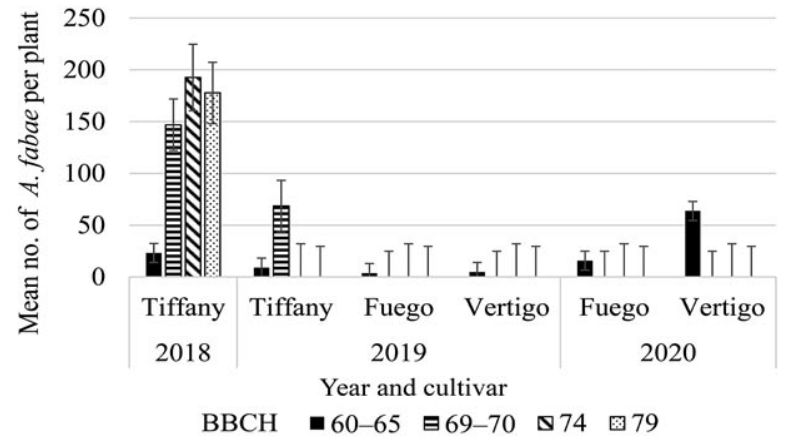

Figure 2. Population of Aphis fabae at different growth stages on broad bean cultivars during 2018-2020 crop growth and reached its peak at the pod formation stage. A. fabae population decreased with increasing temperature till $26-28^{\circ} \mathrm{C}$ for 3 days compared to $20^{\circ} \mathrm{C}$, and the apterae produced more nymphs (Dixon, Wratten, 1971). The temperature rise above $15^{\circ} \mathrm{C}$ is inversely proportional to the abundance of aphids to some extent, as a temperature of $30^{\circ} \mathrm{C}$ gave the lowest longevity and duration of the immature stages for aphids, where the survival curves declined at an earlier age obviously, when temperatures increased from $20^{\circ} \mathrm{C}$ to $30^{\circ} \mathrm{C}$ (Akca et al., 2015). The results agree with those of Kumar and Kumar (2015), who also reported that the population of aphids was influenced negatively by maximum temperature.

The results of our experiment showed that A. fabae population differed among the cultivars and among the years for the same cultivar (Figure 2). The highest infestation of $A$. fabae at BBCH 65 was established on 'Tiffany' in 2019 and it was $100 \%$ higher than that on 'Fuego' and 'Vertigo'. In one week, at BBCH 69-70 growth stages, on 'Tiffany' the abundance of $A$. fabae increased around 7.5 times from 9 to 68 aphids per plant. While on 'Fuego' and 'Vertigo', A. fabae population remained at low abundance (4-5 aphids per plant) during the growing season and dropped to the zero-population density at BBCH 69-70 growth stages. In 2020, 22 days 
after the beginning of infestation, at $\mathrm{BBCH} 65, A$. fabae was more abundant on 'Vertigo' (63.6 aphids per plant) compared to 'Fuego' (15.7 aphids per plant). A rapid decrease in $A$. fabae population was recorded from mid flowering (BBCH 65) to end of flowering (BBCH 69-70) in 2020 on both the cultivars.

Alyokhin et al. (2011) reported that the population of potato aphids was influenced by the weather effects and negatively affected by predators. Therefore, natural enemies as a seven-spot ladybird (Coccinella septempunctata L.) and green lacewing (Chrysoperla rufilabris Bur.) may be a reason for the rapid reduction of A. fabae population in 2019 and 2020. In our experiment, during the 2019 and 2020, the aphid infestation was at different level on 'Vertigo', while the lowest aphid abundance was established on 'Fuego'. The number of aphids continued to increase on 'Tiffany' till the pod development stage (BBCH 70-74) in 2018 and 2019.

All the tested broad bean cultivars were naturally infested with aphids, and the infestation level was variable. The obtained results suggested that there was significant difference in the aphid population on 'Tiffany' only. The highest mean number of aphids in this cultivar was 146.9 and 68.3 aphids per plant during the 2018 and 2019, respectively. The lowest population was observed on 'Fuego' -3.7 and 15.7 aphids per plant during the 2019 and 2020, respectively.

After four years of experiment, Hansen et al. (2008) have concluded that the growing of partially host plant resistant cultivars of field bean will reduce the infestation with black bean aphid. In our experiment, the tested broad bean cultivars also showed different susceptibility to this aphid. As an indicator for establishment of susceptibility to this pest, the intensity of infestation by the mean number of aphids per plant was used. The 'Tiffany' was more infested than the other two tested cultivars 'Fuego' and 'Vertigo'.

Holt and Wratten (1986) found that the concentration of nonprotein amino acids in the leaf and stem extracts was one of the factors, which affected the resistance of broad bean cultivar to $A$. fabae. Resorption of amino acids was much higher in the partially resistant cultivar, which showed little differences in amino acid content and pattern of phloem extracts compared to susceptible cultivars. All of that may depend on genotypes of broad bean cultivars (Ebadah et al., 2006). The population on each cultivar is related to two main parameters, fecundity and longevity of aphids. Meradsi and Laamari (2018) reported that the reproductive period and adult longevity of $A$. fabae on one broad bean cultivar were six times higher than on other cultivar in the same conditions and that led to differences in the number of aphids. Razmjou and Fallahi (2009) found that the population growth characteristics of $A$. fabae can be affected by sugar beet cultivar. In our experiment, 'Fuego' and 'Vertigo' supported a low population density of A.fabae, and these tested cultivars can be used as tool for Integrated Pest Management of aphids in the broad bean. But, on the other hand, the environmental conditions (microclimate) may influence the physiological processes of the plant as well as the insect pest, thus the same cultivar can be the most suitable host for aphids in one site and the worst one in another site (Kumar, 1984).

Aphis fabae control. The data on aphid population occurrence at growth stages $\mathrm{BBCH} 74$ and 79 in 2018 and at BBCH 65 and 69-70 in 2019 and 2020 are presented in Figures 3-6.

Based on the monitoring data in the untreated (control) treatment, in 2018 and 2019 on 'Tiffany', aphid population increased regularly until $\mathrm{BBCH} 74$, then they started declining. But in 2019 and 2020 on 'Fuego' and 'Vertigo', the aphid population plummeted rapidly to zero at $\mathrm{BBCH}$ 69-70 growth stages. In 2018, at $\mathrm{BBCH} 79 \mathrm{~A}$. fabae population was significantly lower for all spray regimes compared to the untreated (control) treatment. The population on the plants treated at early growth stage was significantly higher than for other spray regimes. Maiteki and Lamb (1985) found that early insecticide application did not prevent recovery of aphid population in 2-3 weeks. In our experiment, during the 2018 growing season, all insecticide spray regimes significantly affected $A$. fabae population. The application time of insecticides according to monitoring data, growth stage and local threshold showed a similar aphid control level at BBCH 74 (Figure 3).

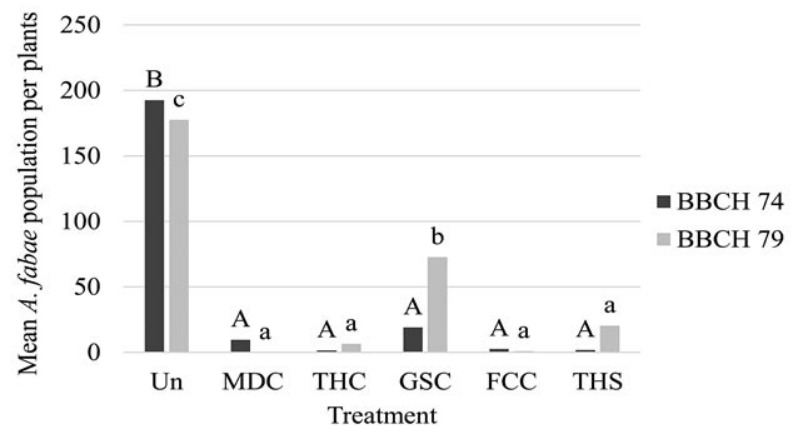

Note. Explanations of treatments under Table 2; columns with the same letter(s) are not significantly different at $P \leq 0.05$.

Figure 3. Aphis fabae control by using insecticide at different spay regimes on the broad bean cultivar 'Tiffany' (2018)

Significant differences among the spray regimes were not established at $\mathrm{BBCH} 74$ and 79, except for the application according to growth stage. Application at stem elongation stage (BBCH 30) was done earlier than the other spray regimes; therefore, the efficacy went down more quickly than in the other treatments. Comparable difference in Acyrthosiphon pisum population was reported for different spray regimes on field peas (Maiteki, Lamb, 1985), where the aphid population recovery started in a short period after an insecticide spray.

In 2019 on 'Tiffany', all insecticide spray regimes significantly affected $A$. fabae population like in 2018 (Figure 4). The aphid population at $\mathrm{BBCH} 65$ and 69-70 growth stages decreased significantly on the plants treated by contact and systemic insecticide according to the local threshold (THS). On the other hand, on the plants treated by contact insecticide according to the local threshold (THC), the aphid population was significantly higher than on the plants treated by systemic insecticide according to the local threshold. In 2019, a very low A. fabae infestation level by was recorded on 'Fuego' and 'Vertigo'. The threshold level was not reached in this growing season. At BBCH $69-70$ growth stages, there was zero-population density in all plots.

In 2020 on 'Fuego', the highest rate of aphids was recorded on the untreated (control) plants and where application was done according to the monitoring data (MD): 15.7 and 15.8 aphids per plant, respectively (Figure 5). The best control was seen when the application had been done according to the local threshold. The same control level tendencies were observed on 'Vertigo' also: the best efficacy was established, when contact and systemic insecticides had been used according to the local threshold (Figure 6). 


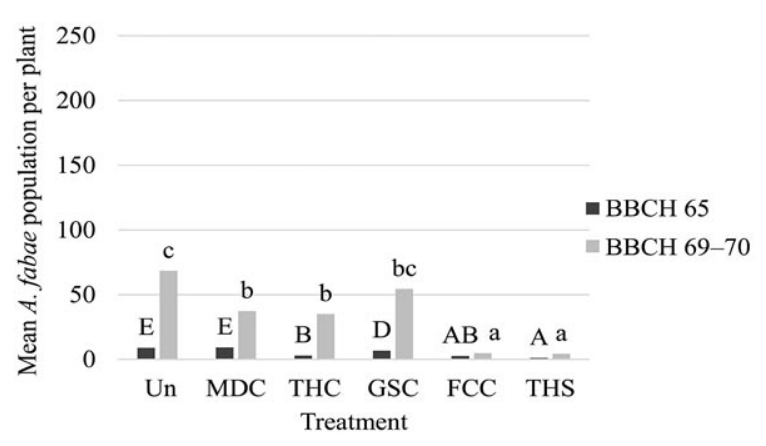

Note. Explanations of treatments under Table 2; columns with the same letter(s) are not significantly different at $P \leq 0.05$.

Figure 4. Aphis fabae control by using insecticide at different spay regimes on the broad bean cultivar 'Tiffany' (2019)

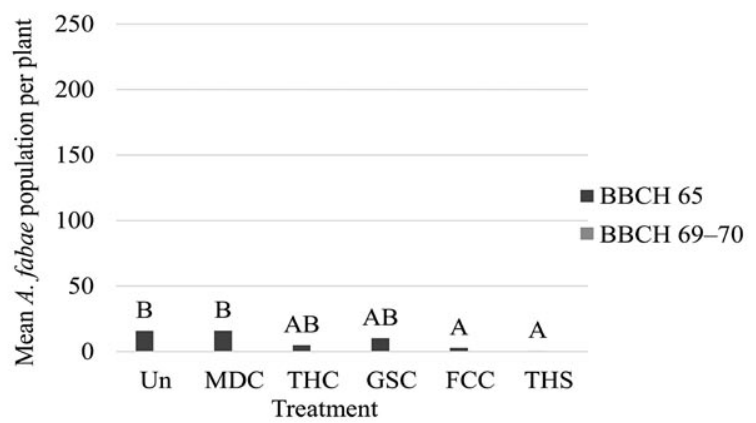

Note. Explanations of treatments under Table 2; not significantly different at $P \leq 0.05$.

Figure 5. Aphis fabae control by using insecticide at different spay regimes on the broad bean cultivar 'Fuego' (2020)

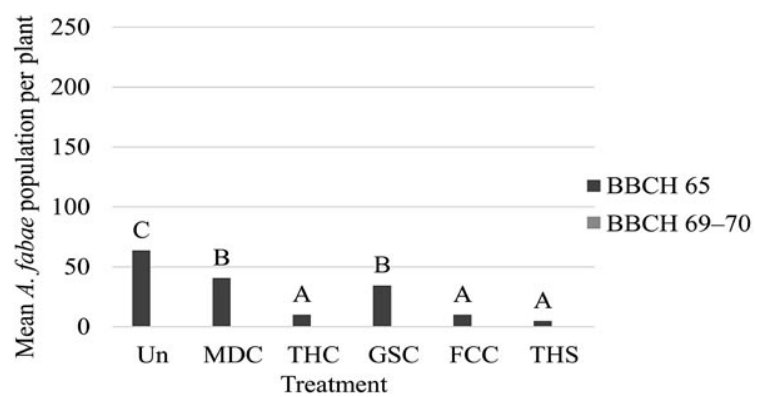

Note. Explanations of treatments under Table 2; not significantly different at $P \leq 0.05$.

Figure 6. Aphis fabae control by using insecticide at different spay regimes on the broad bean cultivar 'Vertigo' (2020)

Similar results were recorded by Kusi et al. (2019), where the abundance of sucking insect pests on cowpea was affected by insecticide spraying time. They found that insecticide sprayed two times gave a lower population of pod sucking bugs compared with sprayed once. The yield loss correlated with the incidence time of the insect pest. Alghali (1992) found that insect pests attacking cowpea at the vegetative stage did less damage than those attacking at the flower bud development stages. Kusi et al. (2019) reported that insecticide applied twice or thrice, which coincided with pod borer thresholds gave effective protection for cowpea.

Results of 2018, 2019 and 2020 for cultivars 'Tiffany', 'Fuego' and 'Vertigo' may be combined, because the response of $A$. fabae to the different insecticide spray regimes was more or less the same for all experimental years, whatever the low $A$. fabae abundance in 2019 and 2020. There were no significant differences of control level at $\mathrm{BBCH} 74$ among the insecticide spray regimes in 2018. However, at BBCH 79, the aphid population slightly recovered in the plots treated at the beginning of stem elongation (the spray regime according to the growth stage, GS) (Figure 5). The reduction in A. fabae population by spray regimes according to the local threshold indicates that it is efficient for the pests control (Figure 4).

The data of our experiment showed that at very low aphid level there were no significant differences in efficacy between the insecticides applied according to the different spray regimes. However, at the high abundance of aphids, early application, when the initial migrants of $A$. fabae are arriving at the broad bean field (spray regime according to the monitoring data, MD) may prevent an increase in aphid population. That agrees with the results of Way et al. (1954), who found that early application with insecticides markedly increases the seed yield of broad bean. Hodgson et al. (2012) reported that suitable insecticide timing is decisive for the control of soybean aphid (Aphis glycines), and the aphids can recover from insecticide applications in the absence of natural enemies.

In our experiment, spray regime according to the local threshold resulted in a significantly lower aphid population compared to the spray regime according to the monitoring data (when the first aphid insect was caught in the yellow water traps), which did not prevent recovery of aphid population in 2019 and 2020 . That may be due to the rapid reproductive rate of aphids (Myers et al., 2005). This agrees with the findings of the study suggesting that the best time for foliar insecticide application to control A. glycines and to ensure the highest yield was according to the economic threshold (Ragsdale et al., 2007). Contrariwise, insecticide application late after aphid population had reached the economic threshold will not cover the cost of the insecticides because of the losses in yield (Johnson et al., 2008).

Aphid severity may vary highly from year to year due to the weather conditions that may reduce the severe attack by aphids, even if most broad bean plants were infested by the initial migrants. Other researchers (Leather et al., 2017) reported that the size of aphids' population was varied by diet quality, abiotic environment and plant growth stage. Some species such as $A$. pisum on similar plant hosts showed variability in population density. Over the experimental years, $A$. fabae population was markedly reduced by the insecticides applied once according to the local threshold. The results are comparable to those of Dewar and Denholm (2017), who has reported that the current recommendation for $A$. fabae control is economically justified, if $A$. fabae population exceeds the economic threshold. But he also reported that insecticide application more than once did not produce significant yield increases because of the tolerance of the new cultivars to aphid colonization. So, to avoid undesired negative effects of insecticides on beneficial organisms as the natural enemies, a careful timing of applications can guide to obtain better control of these sap-sucking insects.

Over the experimental years, the lowest percentages of $A$. fabae infested plants at $\mathrm{BBCH} 79$ were found in the plots treated according to the local threshold using systemic insecticide. They significantly reduced the percentage of infested plants compared the other spray regimes. In 2018 on 'Tiffany', the lowest average percentage of infested plants was recorded for the insecticide spray regimes according to the monitoring 
data $(9.3 \%)$ and full control $(9.3 \%)$, while the growth stage regime had no positive effect $(22.1 \%)$ (Table 3 ).

In 2019, the percentages of infested plants were zero on 'Vertigo' in all treatments, even in the untreated (control), and it was very low on 'Fuego' with no significant differences between the insecticide treatments. On 'Tiffany', the lowest percentage of infested plants was given by both full control and threshold spray regimes
$(4.25 \%$ and $5.25 \%)$ with significant differences compared to the other treatments. All the spray regimes significantly reduced the damage percentage on the plants. In 2020, the application according to the local threshold with systemic insecticide (THS) gave the lowest percentage of infested plants on 'Fuego' and 'Vertigo' $(2.5 \%$ and $6.0 \%)$ (Table 3$)$, and the lowest damage percentage $(10 \%$ and $21 \%$ ) with significant differences compared to the early

Table 3. Mean percentage of Aphis fabae-infested plants of broad bean cultivars in 2018, 2019 and 2020 at BBCH 79 growth stage

\begin{tabular}{|c|c|c|c|c|c|c|}
\hline \multirow{3}{*}{ Treatment } & \multicolumn{6}{|c|}{ Percentage of infested plants $\%$} \\
\hline & 2018 & 2019 & & & 2020 & \\
\hline & 'Tiffany' & 'Tiffany' & 'Fuego' & 'Vertigo' & 'Fuego' & 'Vertigo' \\
\hline $\begin{array}{l}\text { Untreated } \\
\text { (control) }\end{array}$ & $34.9 \pm 2.98 \mathrm{c}$ & $36.75 \pm 3.52 \mathrm{c}$ & $6 \pm 1.78 \mathrm{a}$ & $0 \pm 0.00 \mathrm{a}$ & $26 \pm 6.28 \mathrm{~d}$ & $55.5 \pm 4.03 \mathrm{c}$ \\
\hline $\mathrm{MDC}$ & $9.3 \pm 3.94 \mathrm{ab}$ & $35.75 \pm 1.70 \mathrm{c}$ & $4.25 \pm 0.48 \mathrm{a}$ & $0 \pm 0.00 \mathrm{a}$ & $13.25 \pm 1.65 \mathrm{bc}$ & $30 \pm 8.49 b$ \\
\hline THC & $12 \pm 4.76 \mathrm{ab}$ & $12 \pm 1.68 \mathrm{a}$ & - & - & $7.5 \pm 0.87 \mathrm{abc}$ & $9.5 \pm 1.85 \mathrm{a}$ \\
\hline GSC & $22.1 \pm 2.16 \mathrm{~b}$ & $25.75 \pm 2.25 \mathrm{~b}$ & $5.5 \pm 0.64 \mathrm{a}$ & $0 \pm 0.00 \mathrm{a}$ & $13.5 \pm 0.96 \mathrm{bc}$ & $19 \pm 2.68 \mathrm{ab}$ \\
\hline FCC & $9.3 \pm 3.89 \mathrm{ab}$ & $4.25 \pm 1.03 \mathrm{a}$ & - & $0 \pm 0.00 \mathrm{a}$ & $4.75 \pm 0.85 \mathrm{ab}$ & $11.75 \pm 0.75 \mathrm{a}$ \\
\hline THS & $20 \pm 6.87 \mathrm{ab}$ & $5.25 \pm 0.48 \mathrm{a}$ & - & - & $2.5 \pm 0.50 \mathrm{a}$ & $6 \pm 1.08 \mathrm{a}$ \\
\hline
\end{tabular}

Note. Explanations of treatments under Table 2; means within each column followed by the same letter(s) are not significantly different at $P \leq 0.05$; mean $\pm \mathrm{SE}$ (standard error).

treatment (application according to monitoring data) (Table 4).

In 2018, all spray regimes reduced the infested area by $A$. fabae on the plant compared to the untreated (control) treatment at BBCH 79 (Table 4). The lowest infested area percentage was recorded in the early treated plants according to the monitoring data (11\%) followed by treated according to threshold (18\%). There were no significant differences between the application times. In 2019, the percentages of infested area were zero on 'Vertigo' in the untreated (control) and the other treatments. On 'Fuego', there were no significant differences between the treatments. In 2019 on 'Tiffany', the lowest percentage of infested area was recorded in the plots that had been treated three times (full control, FCC) (14\%) and in the plots treated according to the local threshold (16\%) with significant differences compared to the other insecticide and untreated (control) treatments.

Table 4. Mean total Aphis fabae-infested area per plant of broad bean cultivars in 2018, 2019 and 2020 at BBCH 79 growth stage

\begin{tabular}{ccccccc}
\hline \multirow{2}{*}{ Treatment } & \multicolumn{5}{c}{ Aphid-infested area per plant \% } \\
\cline { 2 - 7 } & \multicolumn{2}{c}{2018} & 2019 & \multicolumn{5}{c}{2020} \\
\cline { 2 - 7 } & 'Tiffany' & 'Tiffany' & 'Fuego' & 'Vertigo' & 'Fuego' & 'Vertigo' \\
\hline Untreated & $48 \pm 3.65 \mathrm{c}$ & $42 \pm 2.82 \mathrm{~cd}$ & $11 \pm 1.91 \mathrm{a}$ & $0 \pm 0.00 \mathrm{a}$ & $55 \pm 6.61 \mathrm{~d}$ & $82 \pm 2.58 \mathrm{~d}$ \\
(control) & $11 \pm 4.43 \mathrm{ab}$ & $51 \pm 3.41 \mathrm{~d}$ & $13 \pm 2.51 \mathrm{a}$ & $0 \pm 0.00 \mathrm{a}$ & $35 \pm 3.00 \mathrm{c}$ & $59 \pm 9.71 \mathrm{c}$ \\
MDC & $18 \pm 7.39 \mathrm{ab}$ & $26 \pm 3.64 \mathrm{ab}$ & - & - & $27 \pm 2.52 \mathrm{bc}$ & $25 \pm 3.00 \mathrm{a}$ \\
THC & $28 \pm 2.82 \mathrm{~b}$ & $36 \pm 1.63 \mathrm{bc}$ & $17 \pm 2.52 \mathrm{a}$ & $0 \pm 0.00 \mathrm{a}$ & $32 \pm 2.83 \mathrm{c}$ & $49 \pm 5.97 \mathrm{bc}$ \\
GSC & $16 \pm 5.66 \mathrm{ab}$ & $14 \pm 2.58 \mathrm{a}$ & - & $0 \pm 0.00 \mathrm{a}$ & $18 \pm 2.58 \mathrm{ab}$ & $33 \pm 2.52 \mathrm{ab}$ \\
FCC & $26 \pm 8.41 \mathrm{ab}$ & $16 \pm 0.00 \mathrm{a}$ & - & - & $10 \pm 2.00 \mathrm{a}$ & $21 \pm 3.78 \mathrm{a}$ \\
THS &
\end{tabular}

Note. Explanations of treatments under Table 2; means within each column followed by the same letter(s) are not significantly different at $P \leq 0.05 ;$ mean $\pm \mathrm{SE}$ (standard error).

The results can be explained by the fact that the systemic insecticide residues were in the plant tissues with a sufficient concentration to kill a large number of aphids feeding on the sap contaminated with the insecticide (Al-Naser, Ezz Al-dden, 2011). Similar results indicated that neonicotinoid insecticides were highly effective against aphids and reduced their population under the field conditions (Gerami et al., 2012; Abd-Ella, 2014). On the other hand, the lower efficacy of cypermethrin against aphids may be due to its toxicity to ladybirds (coccinellids), which are the main natural enemies against aphids. A. fabae population, where the coccinellids are absent, is developing faster than the population attacked by coccinellids (Kindlmann et al., 2015). The toxicity of cypermethrin to coccinellids has been reported by Wagh et al. (2017), while Fitzgerald (2004) reported that that neonicotinoid insecticides did not show detriment to some predators as Chrysoperla carnea.

The seed yield did not differ significantly among the treatments. Applications according to the local threshold with contact and systemic insecticide gave similar grain yield, and it was in line with the full control treatment. This data suggested that the application according to the local threshold ensured sufficient control of aphids and prevented yield loss.

Way et al. (1954) reported that when the A.fabae attack was slight, there were no significant differences in seed yield between the insecticidal treatments and the untreated (control) one. The plots treated against aphids gave higher yield, but it did not differ significantly compared to the untreated treatment (Khan et al., 2012).

\section{Conclusions}

1. All the tested broad bean cultivars were variably infested with black bean aphid (Aphis fabae). The experimental data suggest that among the three cultivars tested, 'Tiffany' was the most susceptible to A. fabae, while 'Fuego' and 'Vertigo' supported a low population density of this pest; the latter two cultivars 
can be used as a tool for Integrated Pest Management of aphids in the broad bean.

2. Insecticides applied according to the local threshold resulted in a significantly lower aphid population compared to that in the untreated (control) treatment, and the efficacy was at a similar level with the full control treatment.

3. The data from the four field trials conducted during the three growing seasons suggest that $A$. fabae infestation can result in a grain yield reduction of 0.21 $\mathrm{t} \mathrm{ha} \mathrm{a}^{-1}$. Applications of contact and systemic insecticides according to the local threshold gave a similar yield increase, and it was in line with the full control treatment.

\section{Acknowledgements}

The authors would like to thank the technical team of the Department of Plant Pathology and Protection of Institute of Agriculture, Lithuanian Research Centre for Agriculture and Forestry for their contribution to this research.

Received 17082020 Accepted 17022021

\section{References}

Abd-Ella A. A. 2014. Toxicity and persistence of selected neonicotinoid insecticides on cowpea aphid, Aphis craccivora Koch (Homoptera: Aphididae). Archives of Phytopathology and Plant Protection, 47 (3): 366-376. https://doi.org/10.1080/03235408.2013.809919

Akca I., Ayvaz T., Yazici E., Smith C. L., Chi H. 2015. Demography and population projection of Aphis fabae (Hemiptera: Aphididae): with additional comments on life table research criteria. Journal of Economic Entomology, 108 (4): 1466-1478. https://doi.org/10.1093/jee/tov187

Al-Naser Z., Ezz Al-dden D. 2011. The chemical control of black bean aphid (Aphis fabae Scopoli.) and their effects on morphological characters and yield of broad bean (Vicia $f a b a$ L.). The Arab Journal for Arid Environments 6 (2): 89-96 (in Arabic).

Alghali A. M. 1992. Insecticide application schedules to reduce grain yield losses caused by insects of cowpea in Nigeria. International Journal of Tropical Insect Science, 13 (5): 725-730. https://doi.org/10.1017/S1742758400007967

Alyokhin A., Drummond F. A., Sewell G., Storch R. H. 2011. Differential effects of weather and natural enemies on coexisting aphid populations. Environmental entomology, 40 (3): 570-580. https://doi.org/10.1603/EN10176

Blackman R. L., Eastop V. F. 2017. Taxonomic issues. Van Emden H. F., Harrington R. (eds). Aphids as crop pests. CABI, chapter 1, p. 1-36. https://doi.org/10.1079/9781780647098.0001

Choudhary A. L., Hussain A., Choudhary M. D., Samota R., Jat S. L. 2017. Bioefficacy of newer insecticides against aphid, Aphis craccivora Koch on cowpea. Journal of Pharmacognosy and Phytochemistry, 6 (4): 1788-1792.

Dedryver C.-A., Le Ralec A., Fabre F. 2010. The conflicting relationships between aphids and men: a review of aphid damage and control strategies. Comptes Rendus Biologies, 333 (6-7): 539-553. https://doi.org/10.1016/j.crvi.2010.03.009

Dewar A. M., Denholm I. 2017. Chemical control. Van Emden H. F., Harrington R. (eds). Aphids as Crop Pests. CABI. chapter 18. p. 398-425. https://doi.org/10.1079/9781780647098.0398

Dixon A. F. G., Wratten S. D. 1971. Laboratory studies on aggregation, size and fecundity in the black bean aphid, Aphis fabae Scon. Bulletin of Entomological Research. 61 (1): 97-111. https://doi.org/10.1017/S0007485300057485
Dotasara S. K., Agrawal N., Singh N., Swami D. 2017. Efficacy of some newer insecticides against mustard aphid Lipaphis erysimi Kalt. in cauliflower. Journal of Entomology and Zoology Studies, 5 (2): 654-656.

Ebadah I. M. A., Mahmoud Y. A., Moawad S. S. 2006. Susceptibility of some faba bean cultivars to field infestation with some insect pests. Research Journal of Agriculture and Biological Sciences, 2 (6): 537-540.

Esmaeili-Vardanjani M., Askarianzadeh A., Saeidi Z., Hasanshahi G. H., Karimi, J., Nourbakhsh S. H. 2013. A study on common bean cultivars to identify sources of resistance against the black bean aphid, Aphis fabae Scopoli (Hemiptera: Aphididae). Archives of Phytopathology and Plant Protection. 46 (13): 1598-1608.

https://doi.org/10.1080/03235408.2013.772351

Fitzgerald J. 2004. Laboratory bioassays and field evaluation of insecticides for the control of Anthonomus rubi, Lygus rugulipennis and Chaetosiphon fragaefolii, and effects on beneficial species, in UK strawberry production. Crop Protection, 23 (9): 801-809 https://doi.org/10.1016/j.cropro.2003.12.005

Gerami S., Talebi K., Bandani A., Ghadamyari M., Hosseininaveh V. 2012. Relationship between susceptibility to neonicotinoids and population dynamics of cotton aphid, Aphis gossypii Glover (Hemiptera: Aphididae). Archives of Phytonathology and Plant Protection, 45 (2): 192-198. https://doi.org/10.1080/03235408.2010.522815

Goszczyński W., Cichocka E., Leszczyński B. 2002. Beetroot damage due to the black bean aphid (Aphis fabae Scop) infestation. Electronic Journal of Polish Agricultural Universities, 5 (2): \#02. http://www.ejpau.media.pl/ volume $5 /$ issue $2 /$ horticulture/art-02.html

Hansen L. M., Lorentsen L., Boelt B. 2008. How to reduce the incidence of black bean aphids (Aphis fabae Scop.) attacking organic growing field beans (Vicia faba L.) by growing partially resistant bean varieties and by intercropping field beans with cereals. Acta Agriculturae Scandinavica, Section B: Soil and Plant Science. 58 (4): 359-364. https://doi.org/10.1080/09064710701788844

Hodgson E. W., McCornack B. P., Tilmon K., Knodel J. J. 2012. Management recommendations for soybean aphid (Hemiptera: Aphididae) in the United States. Journal of Integrated Pest Management, 3 (1): E1-E10. https://doi.org/10.1603/IPM11019

Holt J., Wratten S. D. 1986. Components of resistance to Aphis fabae in faba bean cultivars. Entomologia Experimentalis et Annlicata. 40 (1): 35-40. https://doi.org/10.1111/j.1570-7458.1986.tb02152.x

Johnson K. D., O'Neal M. E., Bradshaw J. D., Rice M. E. 2008. Is preventative, concurrent management of the soybean aphid (Hemiptera: Aphididae) and bean leaf beetle (Coleoptera: Chrysomelidae) possible? Journal of Economic Entomology. 101 (3): 801-809. https://doi.org/10.1093/jee/101.3.801

Johnson K. D., O'Neal M. E., Ragsdale D. W., DiFonzo C. D., Swinton S. M., Dixon P. M., Potter B. D., Hodgson E. W., Costamagna A. C. 2009. Probability of cost-effective management of soybean aphid (Hemiptera: Aphididae) in North America. Journal of Economic Entomology, 102 (6): 2101-2108. https://doi.org/10.1603/029.102.0613

Khan A. M., Khan A. A., Afzal M., Iqbal M. S. 2012. Wheat crop yield losses caused by the aphids infestation. Journal of Biofertilizers and Biopesticides, 3 (4): 55983744. https://doi.org/10.4172/2155-6202.1000122

Kindlmann P., Yasuda H., Kajita Y., Sato S., Dixon A. F. G. 2015. Predator efficiency reconsidered for a ladybird-aphid system. Frontiers in Ecology and Evolution, 3: 27. https://doi.org/10.3389/fevo.2015.00027

Kumar R. 1984. Insect pest control with special reference to African agriculture. London, UK, 298 p.

Kumar A., Kumar A. 2015. Effect of abiotic and biotic factors on incidence of pests and predator in cowpea (Vigna unguiculata (L.) Walp.). Legume Research-An International Journal. 38 (1): 121-125. https://doi.org/10.5958/0976-0571.2015.00020.X 
Kusi F., Nboyine J. A., Abudulai M., Seidu A., Agyare Y. R., Sugri I., Zakaria M., Owusu R. K., Nutsugah S. K., Asamoah L. 2019. Cultivar and insecticide spraying time effects on cowpea insect pests and grain yield in northern Ghana. Annals of Agricultural Sciences, 64 (1): 121-127. https://doi.org/10.1016/j.aoas.2019.03.001

Leather S. R., Awmack C. S., Garratt M. P. D. 2017. Growth and development. Van Emden H. F., Harrington R. (eds). Aphids as Crop Pests. CABI, chapter 6, p. 98-113. https://doi.org/10.1079/9781780647098.0098

Magalhaes L. C., Hunt T. E., Siegfried B. D. 2009. Efficacy of neonicotinoid seed treatments to reduce soybean aphid populations under field and controlled conditions in Nebraska. Journal of Economic Entomologv. 102 (1): 187-195. https://doi.org/10.1603/029.102.0127

Maiteki G. A., Lamb R. J. 1985. Spray timing and economic threshold for the pea aphid, Acyrthosiphon pisum (Homoptera: Aphididae), on field peas in Manitoba. Journal of Economic Entomology, 78 (6): 1449-1454. https://doi.org/10.1093/jee/78.6.1449

Meradsi F., Laamari M. 2018. Behavioral and biological responses of black bean aphid (Aphis fabae, Scopoli, 1763) on seven Algerian local broad bean cultivars. Acta Agriculturae Slovenica, 111 (3): 535-543. https://doi.org/10.14720/aas.2018.111.3.02

Myers S. W., Hogg D. B., Wedberg J. L. 2005. Determining the optimal timing of foliar insecticide applications for control of soybean aphid (Hemiptera: Aphididae) on soybean. Journal of Economic Entomologv. 98 (6): 2006-2012. https://doi.org/10.1603/0022-0493-98.6.2006

Narjary B., Adak T., Meena M. D., Chakravarty N. V. K. 2013. Population dynamics of mustard aphid in relation to humid thermal ratio and growing degree days. Journal of Agricultural Physics, 13 (1): 39-47.

Patil S. S., Sridevi D., Ramesh Babu T. R., Pushpavathi B. 2017. Relative efficacy of selected insecticides on cowpea aphid, Aphis craccivora (Koch). Journal of Entomology and Zoology Studies, 5 (5): 1603-1607.

Purhematy A., Ahmadi K., Moshrefi M. 2013. Toxicity of thiacloprid and fenvalerate on the black bean aphid, Aphis fabae, and biosafety against its parasitoid, Lysiphlebus fabarum. Journal of Biopesticides, 6 (2): 207.
Ragsdale D. W., McCornack B. P., Venette R. C., Potter B. D., MacRae I. V., Hodgson E. W., O'Neal M. E., Johnson K. D., O’Neil R. J., DiFonzo C. D., Hunt T. E., Glogoza P. A., Cullen E. M. 2007. Economic threshold for soybean aphid (Hemiptera: Aphididae). Journal of Economic Entomology, 100 (4): $1258-1267$. https://doi.org/10.1093/jee/100.4.1258

Razmjou J., Fallahi A. 2009. Effects of sugar beet cultivar on development and reproductive capacity of Aphis fabae. Bulletin of Insectology, 62 (2): 197-201.

Rondon S. I., Thompson D. I. 2019. Efficacy of neonicotinoid insecticides controlling aphids and Colorado potato beetle in potatoes grown under central pivot irrigation, 2018. Arthronod Management Tests, 44 (1): tsz001. https://doi.org/10.1093/amt/tsz001

Roy S. K., Ali M. S., Mony F. T. Z., Islam M. S., Matin M. A. 2014. Chemical control of whitefly and aphid insect pest of French bean (Phaseolus vulgaris L.). Journal of Bioscience and Agriculture Research. 2 (2): 69-75. https://doi.org/10.18801/jbar.020214.21

Stoddard F. L., Nicholas A. H., Rubiales D., Thomas J., VillegasFernández A. M. 2010. Integrated pest management in faba bean. Field Crons Research. 115 (3): 308-318. https://doi.org/10.1016/j.fcr.2009.07.002

Subedi B., Acharya K., Kafle K. 2018. Effectiveness of plant leaf extract on black bean aphid (Aphis fabae Linn.). Innovative Techniques in Agriculture, 2 (3): 395-399.

Tamošiūnas K. 1993. The most important pests on faba beans and their control: doctoral dissertation. Lithuanian University of Agriculture, 129 p. (in Lithuanian).

Wagh B. M., Pagire K. S., Thakare D. P., Birangal A. B. 2017. Management of sucking pests by using newer insecticides and their effect on natural enemies in tomato (Lycopersicon esculentum Mill.). International Journal of Current Microbiology and Anplied Sciences, 6 (4): 615-622. https://doi.org/10.20546/ijcmas.2017.604.074

Way M. J., Smith P. M., Potter C. 1954. Studies on the bean aphid (Aphis fabae Scop.) and its control on field beans. Annals of Applied Biology, 41 (1): 117-131. https://doi.org/10.1111/j.1744-7348.1954.tb00920.x

\title{
Pupinių amarų (Aphis fabae Scop.) išplitimas ir kontrolė pupose
}

\author{
M. Almogdad, R. Semaškienė \\ Lietuvos agrarinių ir miškų mokslų centras
}

\section{Santrauka}

Siekiant ịvertinti pupinių amaru (Aphis fabae Scop.) populiacijos pokyčius priklausomai nuo auginamos veislès ir kenkejjo kontrolès laiko naudojant insekticidus, paprastujų pupų (Vicia faba L.) pasèliuose trejus (2018, 2019 ir 2020) metus buvo vykdytas tikslusis lauko eksperimentas. Augintos trijų veislių - 'Tiffany', 'Fuego' ir 'Vertigo' - pupos. Eksperimento laukeliai buvo išdèstyti 1-2 km atstumu vienas nuo kito. Eksperimento metu buvo taikyti penki purškimo laiko režimai. Amarų populiacija stebėta nuo žydejjimo pradžios iki ankščių vystymosi tarpsnio. Tarp purškimo režimų esminiai skirtumai buvo nustatyti pupinių amarų populiacijos, užkrèstų augalų procento ir pažeidimo procento. Aphis fabae išplitimas ant tirtų veislių pupų varijavo. Tyrimo duomenimis, iš trijų tirtų veislių A. fabae buvo jautriausios veislès 'Tiffany' pupos, o veislių 'Fuego' ir 'Vertigo' augaluose amarų populiacija buvo negausi. Purškiant pagal žalingumo ribą, amarų populiacija esmingai sumažèjo, lyginat su nepurkštu kontroliniu variantu, o insekticidų veiksmingumas buvo panašus, lyginant su visiška apsauga nuo šio kenkejo.

Keturių laukelių eksperimento, vykdyto tris auginimo sezonus, duomenimis, pupų pasèlyje išplitus $A$. fabae, grūdų derlius gali sumažèti $0,21 \mathrm{t} \mathrm{ha}^{-1}$. Pagal žalingumo ribą nupurškus kontaktiniu ir sisteminiu insekticidais, grūdų derliaus padidejjimas atitiko visiškos amarų kontrolès variantą.

Reikšminiai žodžiai: Aphis fabae, gausumas, vietinė žalingumo riba, insekticidai, Vicia faba, derlius. 